\title{
Putting technological, pedagogical, and content knowledge (TPACK) in action: An integrated TPACK-design-based learning (DBL) approach
}

\author{
Evrim Baran and Erdem Uygun \\ Middle East Technical University, Turkey
}

\begin{abstract}
Design-based learning (DBL) has been considered a useful approach in teacher education because of its emphasis on the investigation of technology integration problems in design processes. Despite recent interest in understanding how technological, pedagogical, and content knowledge (TPACK) translates to action, limited research exists on how TPACK is developed within DBL contexts and what principles of DBL can be applied to TPACK development. To address these critical gaps in the literature, an approach was developed that outlined eight DBL principles that foster understanding of TPACK-in-action in teacher education contexts. Next, a graduate course was designed to determine how course activities facilitated understanding of TPACK-in-action and to what extent students enacted TPACK-DBL principles. Following a case study methodology, data were collected from 10 graduate students through reflection reports, design guides, and researcher observation notes. The analysis of qualitative and descriptive data revealed that as a result of TPACK-DBL activities, students developed a four-dimensional understanding of TPACK-in-action: theory-practice connection, readiness for practice, technological proficiency, and sustainable learning of TPACK. The results offer recommendations to teacher educators for developing understanding of TPACK-in-action through DBL activities.
\end{abstract}

Preparing teachers for effective technology integration is an ongoing challenge. Since its introduction by Mishra and Koehler (2006), teacher educators and researchers have embraced the technological pedagogical content knowledge (TPACK) framework as a tool for thinking about and applying technology meaningfully in teacher education contexts (Chai, Koh, \& Tsai, 2013; Voogt, Fisser, Roblin, Tondeur, \& van Braak, 2013). Researchers have explored approaches and strategies for developing TPACK in pre-service and in-service contexts to equip teachers with enhanced knowledge, skills, and attitudes related to effective technology integration. Particularly, TPACK-in-action has become a critical focus for understanding how TPACK is reflected in practice (Harris \& Hofer, 2011).

Providing hands-on experience is important in developing complex and multidimensional TPACK. Designbased learning (DBL) approaches have been considered useful in helping teachers bridge theoretical knowledge with practice, and a number of design pedagogies have been integrated into teaching contexts to investigate the development of TPACK (Angeli \& Valanides, 2009; Koh \& Divaharan, 2011; Mishra \& Koehler, 2006). Koehler and Mishra (2005b) suggested that designing authentic teaching situations is one of the best methods for developing TPACK. Chai et al. (2013) pointed to an existing need for research on teachers' design literacy to promote creative and flexible applications of TPACK. Some studies found that design tasks centred on TPACK increased teachers' TPACK scores (Angeli \& Valenides, 2009), yet few studies have investigated what principles of DBL could be applied to enhance TPACK development further. To address these critical gaps in the literature, we investigated TPACK using DBL activities in a customdesigned graduate course. The proposed approach emerged from the literature on TPACK and DBL and included a set of learning design principles to develop TPACK in authentic contexts.

\section{DBL as an approach for developing TPACK}

The complex nature of TPACK requires the study of its development in authentic contexts with hands-on design activities. Design approaches have been used by educators because of their emphasis on inquiry in 
complex environments (Koehler, Mishra, \& Yahya, 2007). Design "allows for significant variables and relationships to be discovered in the naturalistic environment of classrooms" (Koh \& Divaharan, 2013, p. 235). It also offers meaningful exposure to technology integration in educational contexts by directly and actively involving learners (e.g., in-service teachers, pre-service teachers) and demonstrating how technology, pedagogy, content, and contextual factors mutually reinforce and/or constrain each other.

Design activities offer participants rich opportunities to understand the relationships between and among content, pedagogy, and technology more thoroughly (Koehler, Mishra, Hershey, \& Peruski, 2004; Koehler \& Mishra, 2005a, 2005b). Real design challenges clarified misconceptions and addressed holes in knowledge bases through concrete, comprehensible, and meaningful learning. DBL has since been used in higher education (e.g., Alayyar, 2011; Jang \& Chen, 2010), as well as integrated into TPACK development research by a number of scholars because of its positive impact on learning complex and interrelated ideas (Johnson, 2012; Mishra \& Koehler, 2006). Emphasising the investigation of technology integration problems in design processes, or learning technology by design, has been adopted into teacher education contexts where participants worked in groups to identify optimal solutions to instructional technology problems (e.g., Alayyar, 2011; Jang \& Chen, 2010; Koehler et al., 2004; Koehler et al., 2007; Koehler \& Mishra, 2005b). The aim was to develop technology integration knowledge that could be used in classrooms (Johnson, 2012).

DBL approaches have been applied to TPACK in the following contexts:

- $\quad$ pre-service teacher education (Agyei \& Voogt, 2012; Angeli \& Valanides, 2009; Chai, Koh, \& Tsai, 2010; Chien, Chang, Yeh, \& Chang, 2012; Graham, Borup, \& Smith, 2012; Koh \& Divaharan, 2011; Koh \& Divaharan, 2013; Mouza, Karchmer-Klein, Nandakumar, Yilmaz Ozden, \& Hu, 2014; Pamuk, 2012; Srisawasdi, 2012)

- faculty professional development (Koehler \& Mishra, 2005b; Koehler et al., 2007; Rienties, Brouwer, \& Lygo-Baker, 2013)

- in-service teacher training (Guzey \& Roehrig, 2009; Jimoyiannis, 2010; Jimoyiannis, Tsiotakis, Roussinos, \& Siorenta, 2013; Koh \& Divaharan, 2011; Prieto, Villagrá-Sobrino, Jorrín-Abellán, Martínez-Monéz, \& Dimitriadis, 2011).

Results showed significant changes in the development of TPACK within several design contexts (Alayyar, 2011; Jang \& Chen, 2010; Koehler et al., 2007; Koehler \& Mishra, 2005a, 2005b).

With the recent focus on the integration of design activities and TPACK in teacher education programs, this research intended to generate principles of DBL drawn from the literature that may help to develop TPACK in pre-service and in-service teacher education contexts. This set of principles is called the TPACK-DBL approach.

\section{TPACK-DBL: Developing TPACK in teacher education contexts with DBL}

TPACK-DBL outlines eight design principles of teacher education environments that foster learners' (e.g., pre-service teachers, in-service teachers) TPACK development (see Figure 1). These principles are brainstorming of design ideas, design of technology-integrated artefacts, examination of design examples, engagement with theoretical knowledge, investigation of information and communication technology (ICT) tools, reflection on design experiences, applying design in authentic settings, and collaboration within design teams. 


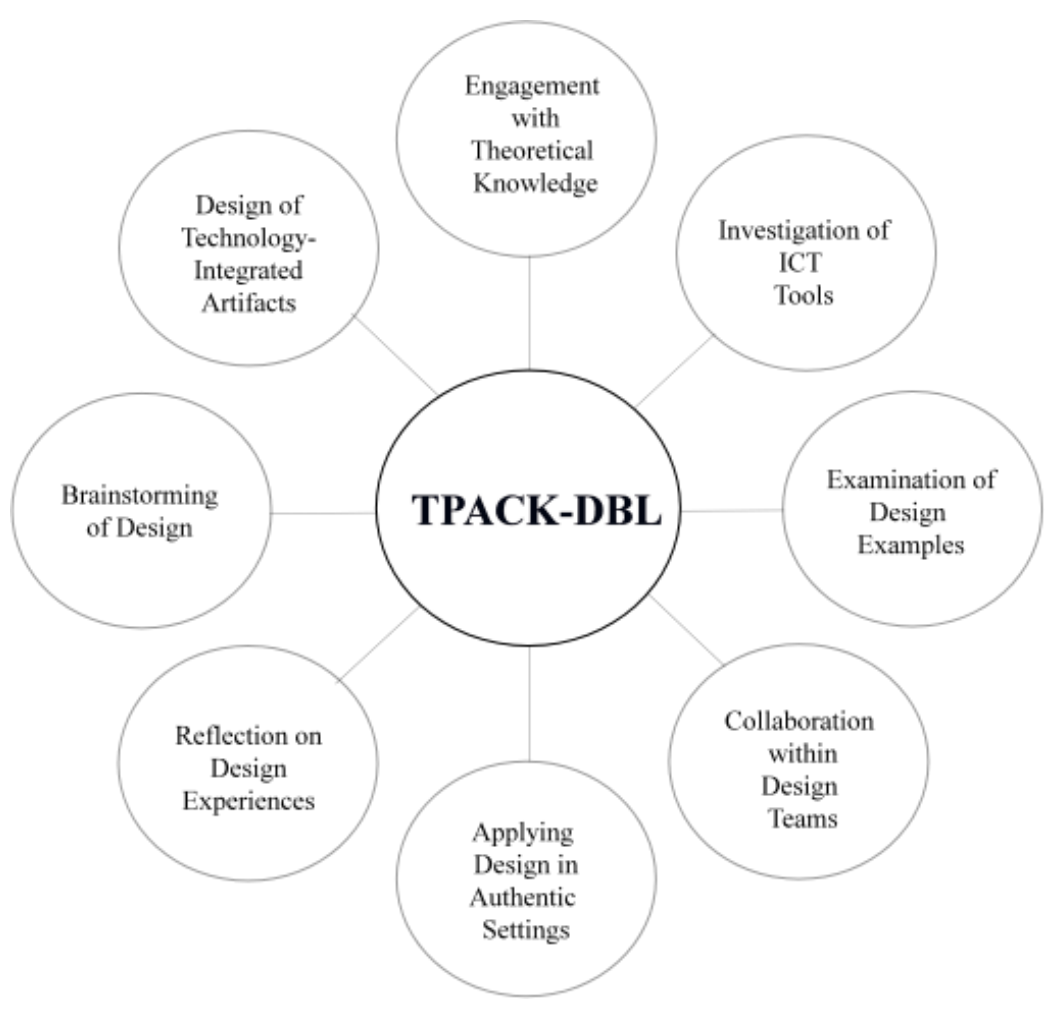

Figure 1. TPACK-DBL principles

The first principle is the brainstorming of design ideas. DBL research has often used brainstorming as a method for discussing potential solutions to technology integration problems (Chai et al., 2010; Graham et al., 2012). During brainstorming, learners ponder imaginative ideas for lessons and activities. For example, Graham et al. (2012) assigned three design tasks to pre-service teachers and asked them to describe how they would teach a particular curriculum objective using technology. Brainstorming allows learners to see varied solutions to technology integration problems, rather than focusing on single and generic solutions.

The second principle is the design of technology-integrated artefacts, such as TPACK-based lesson plans (Agyei \& Voogt, 2012; Angeli \& Valanides, 2009; Chai et al., 2010; Graham et al., 2012; Jimoyiannis, 2010; Jimoyiannis et al., 2013; Koehler \& Mishra, 2005b; Koh \& Chai, 2014; Koh \& Divaharan, 2011; Mouza et al., 2014). Koehler and Mishra (2005b) used a learning-technology-by-design approach, applying the strategies to the creation of artefacts. Graduate students and faculty members worked together to propose solutions to ill-structured educational situations that they might experience in real classroom contexts, such as creating an online course or a technology-integrated lesson plan. The results indicate that this authentic design challenge enhanced participants' TPACK development, as they moved from considering technology, pedagogy, and content as separate constructs to viewing them as transactional and co-dependent. Jimoyiannis (2010) used a learning-through-design approach where teachers constructed authentic artefacts such as lesson plans, learning activities, and teacher guidelines that could be used in their schools. These tasks helped learners tackle the complexities of technology integration during the design process.

The third principle is the examination of design examples. In DBL contexts, learners can explore and criticise existing materials (e.g., technology-integrated learning scenarios, learning activities, lesson plans) of their own design (Angeli \& Valanides, 2009; Jimoyiannis, 2010), their peers' designs (Angeli \& Valanides, 2009), or other available designs (Agyei \& Voogt, 2012; Koh \& Divaharan, 2013; Mouza et al., 2014). During the 
critique process, learners think deeply about technology, pedagogy, and content and how their blends lead to effective instruction (Mouza et al., 2014). For example, Agyei and Voogt (2012) presented technologyintegrated learning materials on which students conducted critical analysis based on TPACK components. Learners should be encouraged to express their ideas regarding the limitations and affordances of technologies, to suggest improvements using TPACK, and to propose adapted versions.

The fourth principle is engagement with theoretical knowledge. This principle is one of the most common features of DBL approaches in the literature (Agyei \& Voogt, 2012; Chai et al., 2010; Graham et al., 2012; Jimoyiannis, 2010; Koh \& Divaharan, 2013; Koh \& Chai, 2014; Pamuk, 2012). Jimoyiannis (2010) presented learners with a wide range of theoretical themes needed to use technology, pedagogy, and content together in an effective way, such as student-centred approaches and ICT in science education. Similarly, Koh and Chai (2014) arranged teaching sessions in which learners "discussed theories related to the design of ICT lessons that supported authentic, meaningful, self-directed and collaborative learning” (p. 224). Engaging with theoretical knowledge provides learners the necessary foundation for teaching with ICT and designing pedagogically meaningful learning materials.

The fifth principle is the investigation of ICT tools. DBL offers an environment in which learners explore the technical capabilities and pedagogical affordances of ICT tools before designing technology-integrated materials (Angeli \& Valanides, 2009; Chai et al., 2010; Jimoyiannis et al., 2013; Koh \& Divaharan, 2013). For example, Angeli and Valanides (2009) structured lab times during which students learned about several technological tools as they designed ICT-integrated materials. Understanding the benefits and constraints of technologies is critical in TPACK development, and the investigation of ICT tools familiarises learners with their potential.

The sixth principle is reflection on design experiences. DBL approaches in the literature have commonly included a component where learners consider their experiences during design processes (Angeli \& Valanides, 2009; Mouza et al., 2014). For example, Angeli and Valanides (2009) allocated the last week of their research to reflection, as groups shared their experiences with others. Mouza et al. (2014) asked learners to write a narrative report about their experiences during lesson design and teaching. Reflection can help learners elaborate on their experiences, identify difficulties they encountered, and conduct self-assessment of TPACK development.

The seventh principle is applying design in authentic settings. Some DBL approaches in the literature have emphasised the importance of applying designed materials in authentic teaching contexts (Agyei \& Voogt, 2012; Jimoyiannis, 2010; Mouza et al., 2014). One example in pre-service teacher education includes the application of designed materials (e.g., lesson plans) within micro-teaching or field experience (Jimoyiannis, 2010; Mouza et al., 2014). By applying design in authentic settings, pre-service and in-service teachers may elaborate on how TPACK is put into action and what contextual elements affect the implementation of designed lessons.

The eighth principle is collaboration within design teams. When design teams work together on authentic technology integration problems, they may discover several potential solutions. Their task is to identify optimal solutions, not perfect solutions, through the process of "satisficing" (Simon, 1969). This process increases knowledge about the interrelations between technology, pedagogy, and content (Koehler et al., 2004). TPACK develops through the interactions among design team members as they work together to find solutions (Koehler et al., 2007; Agyei \& Voogt, 2012). Collaboration provides learners the opportunity to engage in a joint discourse on effective technology integration.

Although additional features have been identified in the literature, these eight principles are considered the most critical components of DBL for teacher education contexts. To understand how TPACK-DBL facilitates students' understanding of TPACK-in-action and to what extent students enact related principles, a graduate course grounded in the above principles was designed and implemented. 
This research study aimed to understand (a) how the TPACK-DBL approach facilitated students' understanding of TPACK-in-action and (b) to what extent students enacted TPACK-DBL principles in workshop design and implementation.

\section{Methodology}

This case study aimed to capture detailed accounts of students' understanding of TPACK-in-action in different design contexts (Yin, 2003). Case study helped to reveal complex and multifaceted nature of TPACK development through TPACK-DBL activities and triangulation of data from multiple sources. Under the naturalistic notion of transferability (Lincoln \& Guba, 2002), the contexts of teaching were described and defined to provide a detailed account and offer other researchers a basis for comparison to their own unique contexts. Ethical clearance was obtained, guidelines were followed, and participants gave consent for data collection. Pseudonyms are used throughout this paper to protect the privacy of the participants.

\section{Context}

This study took place during the spring semester at a public university in Turkey. Over the course of 14 weeks, 10 graduate students ( 5 males, 5 females) attended the course Research and Practice on Technology in Teacher Education, part of the Curriculum and Instruction graduate program. The purpose of the course was to analyse contemporary issues in teacher education and technology; examine approaches, models, and theories on teacher knowledge of effective technology; and generate projects for enhancing teacher education practice with technology. The course included 14 face-to-face sessions ( 3 hours each, taught by the first author).

\section{Participants}

The participants were 10 graduate students ( 5 males and 5 females) enrolled in the course. Students came from a wide range of disciplinary backgrounds: mathematics education $(n=1)$, English language education $(n$ $=1)$, computer education and instructional technologies $(n=6)$, elementary education $(n=1)$, and science education $(n=1)$. Their teaching experiences ranged from zero to 12 years.

\section{Course design with TPACK-DBL principles}

The graduate course designed with TPACK-DBL principles aimed to provide an overview of concepts, models, approaches, and practices of integrating technologies in teacher education. Course activities included (1) EDTech news social bookmarking, (2) TechDemo, (3) the TPACK game, (4) the TPACK workshop, and (5) a TPACK Wikibook chapter. Each course component was integrated with one or more TPACK-DBL principles. Table 1 presents the course components and corresponding principles: (a) brainstorming of design ideas, (b) design of technology-integrated artifacts, (c) examination of design examples, (d) engagement with theoretical knowledge, (e) investigation of ICT tools, (f) reflection on design experiences, (g) teaching in authentic settings, (h) collaboration within design teams.

Table 1

The design of the course components with TPACK-DBL principles

\begin{tabular}{ll}
\hline Activity & The TPACK-DBL principles \\
\hline 1. EDTech news social bookmarking & $\mathrm{d}, \mathrm{e}$ \\
2. TECHDemo & $\mathrm{e}$ \\
3. The TPACK game & $\mathrm{a}, \mathrm{b}, \mathrm{d}, \mathrm{e}, \mathrm{f}, \mathrm{h}$ \\
4. The TPACK workshop & $\mathrm{a}, \mathrm{b}, \mathrm{c}, \mathrm{d}, \mathrm{e}, \mathrm{f}, \mathrm{g}, \mathrm{h}$ \\
5. The Wikibook chapter & $\mathrm{d}$ \\
\hline
\end{tabular}

The EDTech news social bookmarking activity involved sharing and discussing news related to technology integration in teaching by using the Diigo social bookmarking platform. Students were required to share 
research, blog posts, online forums, and tweets related to a weekly topic with the class's Diigo group. Overall, 225 items were posted during the semester, with technology, education, and TPACK being the most common tags. This activity corresponded to two TPACK-DBL principles: engagement with theoretical knowledge and investigation of ICT tools. Diigo bookmarks allowed students to share and elaborate on technology-integrated learning materials and build a collection of relevant resources.

The TechDemo activity aimed at helping students analyse the technologies that could be integrated into teacher education contexts (e.g., smart boards, mobile apps, simulations). Each week, a student delivered a demonstration that offered analysis of a tool in the teacher training settings and engaged the class in hands-on exploration. Presentations included a summary of the tool's features, potential applications, affordances and limitations, and examples of teacher education contexts. This activity applied the TPACK-DBL principle of investigation of ICT tools.

Throughout the semester, students played adapted versions of the TPACK game, which was first developed at the National Technology Leadership Summit's annual gathering in 2007 (Richardson, 2010). The game includes the selection of technology, pedagogy, and content items drawn randomly from pools prepared by participants beforehand. The main concept is to discuss possible lesson designs using the items chosen. The original game was modified and integrated into the course as a semester-long TPACK-DBL activity. Students were divided into four groups: (a) science education, (b) mathematics education, (c) English language education (ELE), and (d) computer education. Each group included one student in the related disciplinary background as well as students with a computer education background. Students played four TPACK games each week over 7 weeks with selected combinations (see Table 2).

Table 2

Selection rules in the TPACK game

\begin{tabular}{llll}
\hline Sub-games & $\begin{array}{l}\text { Technology selection } \\
\text { rule }\end{array}$ & $\begin{array}{l}\text { Pedagogy selection } \\
\text { rule }\end{array}$ & $\begin{array}{l}\text { Content selection } \\
\text { rule }\end{array}$ \\
\hline 1. Technology non-random & Non-random & Random & Random \\
2. Content non-random & Random & Random & Non-random \\
3. Pedagogy non-random & Random & Non-random & Random \\
4. All random & Random & Random & Random \\
\hline
\end{tabular}

Figure 2 presents one combination that was selected by the science education group.

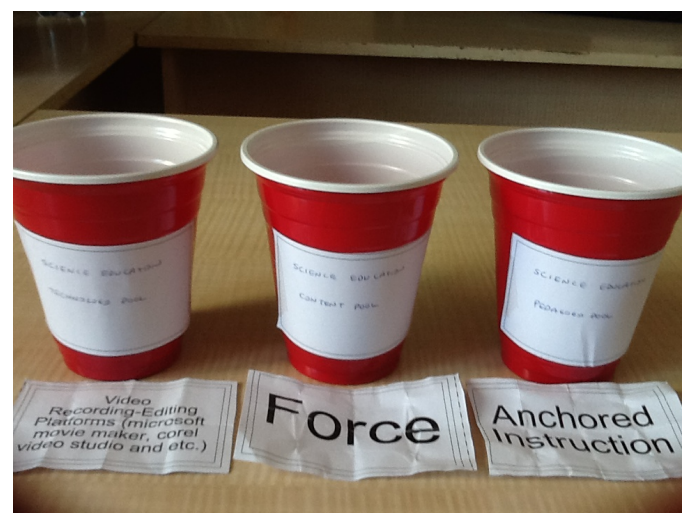

Figure 2. Science education group's TPACK game combination 
Once students completed all the TPACK game combinations, they were asked to select one of their combinations, prepare a lesson plan, and present an exemplary TPACK lesson during their workshops. In order to guide their process, a TPACK lesson plan template and evaluation rubric (Harris, Grandgenett, \& Hofer, 2010) were shared with the students. This activity corresponded with multiple TPACK-DBL principles: brainstorming of design ideas, design of technology-integrated artefacts, engagement with theoretical knowledge, investigation of ICT tools, reflection on design experiences, and collaboration within design teams.

Another major TPACK-DBL activity within the course was the design and delivery of a TPACK workshop for a selected group of participants. The students in the TPACK game groups designed in their content areas and implemented a 3-hour workshop at the end of the semester. The purpose of these workshops was to provide students experience in using technology in their respective disciplinary areas and receive additional support when developing their own ideas. Each group designed a workshop following the guide, implemented it, assessed the impact, and reflected on its effectiveness. The design guide helped students (a) identify the purpose of the workshop, (b) define their audience, (c) assess the needs of the audience through contextual details, (d) specify objectives, (e) plan activities to help participants understand and explore TPACK within their disciplines, and (f) plan to assess participants' TPACK knowledge and the overall effectiveness of the workshop. A total of four design guides were collected from each team. Table 3 presents the guide used to help students design their TPACK workshops.

Table 3

TPACK workshop design guide

Design guide Description

components

\begin{tabular}{|c|c|}
\hline Title & What is the big idea in your workshop? What is it about? \\
\hline Purpose & What is the main purpose of the workshop? What does it want to accomplish overall? \\
\hline $\begin{array}{l}\text { Content } \\
\text { domain }\end{array}$ & $\begin{array}{l}\text { What is the disciplinary area? Unit, lesson, topic? What specific content domain do you } \\
\text { target? }\end{array}$ \\
\hline Audience & $\begin{array}{l}\text { Who is your audience? Who will participate to your workshop? Who can integrate this } \\
\text { workshop into their teacher education context? }\end{array}$ \\
\hline $\begin{array}{l}\text { Needs } \\
\text { assessment }\end{array}$ & $\begin{array}{l}\text { Interview at least two people in your disciplinary area to generate the needs regarding the } \\
\text { integration of technology in teacher education programs (e.g., a science teacher education } \\
\text { domain). Ask specific questions about context, environment (e.g., technology } \\
\text { infrastructure), motivation, technology skills and knowledge). Present your analysis here. }\end{array}$ \\
\hline Context & $\begin{array}{l}\text { After collecting the needs assessment data, provide information on context such as, needs, } \\
\text { technology resources, etc.). }\end{array}$ \\
\hline Objectives & $\begin{array}{l}\text { List specific objectives on what you want the participants achieve at the end of the } \\
\text { workshop overall, and the face to face workshop component specifically (e.g., This } \\
\text { workshop will enable and grow participants' capacity to ...). }\end{array}$ \\
\hline Activities & $\begin{array}{l}\text { What activities do you plan to integrate in your workshop to help your participants } \\
\text { understand and explore TPACK within their disciplines? Why? }\end{array}$ \\
\hline Present & $\begin{array}{l}\text { How do you introduce the purpose and objectives of the workshop as well as TPACK } \\
\text { framework? }\end{array}$ \\
\hline Demonstrate & $\begin{array}{l}\text { You will select one of the TPACK combinations you developed in the TPACK game, } \\
\text { prepare a lesson plan and find an activity to help your audience examine the lesson plan } \\
\text { designed in your specific discipline. }\end{array}$ \\
\hline $\begin{array}{l}\text { Engage and } \\
\text { play }\end{array}$ & $\begin{array}{l}\text { Play the TPACK game with your audience. Brainstorm on how you can play the TPACK } \\
\text { game with this particular audience. }\end{array}$ \\
\hline Dialogue & $\begin{array}{l}\text { Facilitate a dialogue on TPACK. How do you plan to do that? Discussion? Think-pair- } \\
\text { share? Reflection session? Provide potential questions for guided dialogue. }\end{array}$ \\
\hline
\end{tabular}


Once students submitted a draft of their workshop design guides, then they revised these guides based on instructor feedback and implemented the workshop at the end of the semester. Design guides were prepared for 3-hour TPACK workshops by the four participant groups: (a) a cohort of in-service mathematics teachers who had 5 to 10 years of teaching experience, (b) third-year pre-service teachers in elementary science education, (c) pre-service teachers in computer education, and (d) research assistants in the Department of Educational Sciences. The workshop activity corresponded to all TPACK-DBL design principles.

Another major course component was the TPACK Wikibook, which was created by participants. During the semester, each student wrote a chapter focusing on one aspect of TPACK (e.g., science, mathematics, measurement tools, survey research). This collaborative work between the course instructor/editor and the students/authors was intended to present perspectives on the TPACK framework and to establish a theoretical foundation for the experience. Participants created the content as well as the format, such as the cover, title, and table of contents, and published it on the WikiBooks platform (http://www.wikibooks.org/) as an open content textbook. The Wikibook activity was designed under the TPACK-DBL principle of engagement with theoretical knowledge (https://en.wikibooks.org/wiki/The_Many_Faces_of_TPACK).

\section{Data sources and collection}

Three main data sources were used in this study to generate a more complete picture of TPACK development: reflection reports, TPACK workshop design guides, and researcher observations.

Students were asked to complete a TPACK reflection report after the semester ended. The reflection prompts aimed to gather students' thoughts on their own development of TPACK, their insights on the impact of course components on TPACK, the contribution of TPACK activities on society, and their plans for ensuring the continuity and sustainability of learning. A total of 10 reflection reports were gathered with students' answers to the questions, such as:

- How do you evaluate the development of your TPACK throughout the course?

- What contributed the most to your TPACK development?

- What contradicted with what you have already known?

- How do you think the TPACK workshop design/the TPACK game contributed to your development of TPACK?

- How do you evaluate your contribution to society in terms of others' TPACK awareness and development? Reflect on the sustainability of your learning in this course. How will you ensure the continuity of learning for yourself and other stakeholders such as teachers, preservice teachers, teacher educators?

The second data source included the design guides that students prepared for their workshops. A total of four design guides were collected. These guides aimed at helping students prepare their workshops by defining the title, purpose, content domain, audience, needs assessment procedures and analysis, context, objectives, activities, assessments strategies, format, and technology platforms. In the design guide, students were asked to describe how they planned to help participants understand and explore TPACK within their disciplines and to provide detailed plans for each activity.

The third data source encompassed researcher observation notes collected during class hours and TPACK workshops. After each class, observation notes were compared and necessary adaptations and improvements were made to the TPACK-DBL activities. Workshop hours were also observed, and extensive memos were written detailing the context (e.g., space, setting, arrangements, participant characteristics, TPACK activities implemented) and patterns in students' TPACK strategies (e.g., if/how they introduced the framework to the audience, demonstrated content-specific examples, engaged their audience with the TPACK game, and facilitated a dialogue on TPACK). Observations helped determine the alignment between workshop plan guides and actual implementations. 


\section{Data analysis}

In order to understand how the TPACK-DBL approach facilitated students' understanding of TPACK-inaction, students' reflections, design guides, and researcher observation notes were analysed using the thematic analysis approach. Thematic analysis is used for "identifying, analysing, and reporting patterns (themes) within data" (Braun \& Clarke, 2006, p. 6). The steps include familiarising, generating initial codes, searching for themes, reviewing, defining and naming themes, and producing the report. This analysis started with the review of students' reflections and design guides to identify emergent themes. Two researchers reviewing the data sources line by line together recursively and following an open coding procedure extracted a list of codes such as hands-on learning, theory to practice, and think-design-implement. Then, those codes were reviewed and four abstract and inclusive themes were generated: TPACK theory and practice connection, readiness for practice, technological proficiency, and sustainable learning of TPACK. All collected extracts for the codes under each theme were reviewed again to confirm that the data fitted with the theme. Finally, researcher observation notes were reviewed to corroborate themes derived from the iterative analysis of the reflection reports.

\section{Trustworthiness}

Different sources of data were collected in order to triangulate findings. The codes were refined through continuous conversation and negotiation between the two researchers, who coded different data sources together and separately over two months to finalise operational definitions, supply data-driven keywords, and generate examples that demonstrated evidence for each code. During this process, memos were written to document emerging themes and critical incidents. Detailed descriptions of the context were provided to promote the transferability of findings.

\section{Results}

\section{How did the TPACK-DBL activities in the course facilitate students' understanding of TPACK-in-action?}

The analysis of student reflections, design guides, and researchers' observation notes revealed that the TPACK-DBL approach enhanced four dimensions of students' understanding of TPACK-in-action: (a) TPACK theory and practice connection, (b) readiness for practice, (c) technological proficiency, and (d) sustainable learning of TPACK.

\section{TPACK theory and practice connection}

Students commented in their reflections that their understanding of TPACK-in-practice improved as a result of the design activities. When students were asked how the workshop contributed to their development of TPACK, six of them stated that the design and implementation helped them practise teaching TPACK. One participant, Jane, commented on the contributions of the game and workshop design:

With the help of the TPACK game, we had lots of discussions about how to prepare a TPACK lesson plan. We made mistakes and learned from our mistakes. We searched the Internet for examples. We made comparisons between different pedagogies, contents, and technologies ... Learning something and teaching something are very different from each other. When you are teaching, you have lots of responsibilities to other people. That's why, while preparing for the workshop, I studied TPACK from a different perspective. I tried to capture and give the essence of the concept. I tried to find the best examples of TPACK to teach it effectively. For this reason, I also learned many things while trying to organise content and teach.

Because students also collected data about fellow participants' understanding of TPACK during these workshops, they stated that the design activities helped them build their capacity to face real life design 
challenges such as lack of support, infrastructure, or assessment, as well as to identify appropriate technology integration for certain contexts. Lara explained:

Playing the TPACK game and arranging the TPACK workshop with pre-service teachers were the most effective activities that contributed to my TPACK development. Within these activities, with hands-on experiences, we critiqued the use of TPACK, inquired if it could be used or not; if it could be used, we criticised how.

Table 4 presents an example of the design guide prepared by the mathematics education group. While planning a TPACK workshop and then engaging in-service mathematics teachers with the TPACK-LBD activities, students were able to gain practical insights about TPACK-in-action.

Table 4

Mathematics education group's design guide

Describe what specific activities you plan to do to How does this activity address TPACK
engage your audience with TPACK.

Present: A short presentation covering introduction of the TPACK concept, review of the literature regarding how TPACK has been implemented in math education contexts, the implications and results of the studies, and the importance of integrating technology in math teaching and learning.

Demonstrate: A TPACK lesson plan example will be presented. We will discuss how the lesson plan was designed with TPACK elements.

Engage and play: We will play the TPACK game with teachers. A list of topics and technologies will be provided to each group with two to three teachers. Each group will then select a topic and more than one technology that would be used during the activity or lesson. We will provide groups with a guide that includes information about the steps they will follow during lesson plan design.

\section{Dialogue}

- What do you think about the lesson plan you designed?

- Can integrating technology in math education make a difference in classrooms? How? Do you think integration of technology is necessary in math education? Why or Why not?

- What do you think about the future role of TPACK in math education?

- If you used technology in your teaching, what kinds of changes would you make after this workshop?
In-service teachers may have not heard of TPACK, or even PCK, in their pre-service teaching education. Therefore, they are far from knowing the implementation of TPACK in math education. Lacking such important knowledge seems to create a gap in their courses. We plan to close this gap as much as possible with our presentation.

This demonstration will help teachers examine TPACK lesson plan design.

Teachers will design a lesson plan covering each TPACK construct. Once teachers develop their lesson plans, they will then present their lesson plans and explain why they selected certain technologies and how they would implement them in the classrooms.

Discussion questions aim to help math teachers think about the effectiveness of the methods and approaches they use in their courses and ways of improving these lessons with technologies. Discussion will help teachers examine TPACK and the frameworks' potential contribution to their teaching.

Assess: Participants' TPACK will be assessed with the analysis of pre and post-test, workshop video data, examining data, and lesson plans they designed during the TPACK game. 
Researcher observation notes confirmed that the design activities helped students increase their knowledge of technology integration while enacting their designs via several means, such as writing a Wikibook chapter, building lessons with TPACK game combinations, and designing and implementing the workshops. Six out of 10 students did, however, note some challenges. Two students felt that design activities that accumulated towards the end of semester increased their workload, while another explained that a longer time frame to design a series of workshops would help participants understand and practise TPACK more fully.

\section{Readiness for practice}

Half of the students identified preparatory activities such as lesson planning during the TPACK game and preparing workshop design guides as steps for implementation in authentic teaching environments. Over the course of 7 weeks playing the TPACK game, students not only planned four different lesson ideas, but they also chose one component around which to design a plan and present it as an exemplary TPACK lesson within their workshops. This process, noted by the students in reflections, helped them tackle practical issues during their workshops. Kim, for example, when asked about how the TPACK game and lesson plan development affected the implementation of their TPACK workshop, explained how the TPACK game helped prepare for the workshop:

The TPACK game was the most beneficial activity for me. Especially the "randomly selected" option made me think deeper about TPACK, and it was very helpful to understand TPACK. Moreover, the game was a preparation for the workshop. The only change was the roles: I was learning as a student in the games, and I taught as a teacher in the workshop. Thus, I did not have any big problems during the workshop since I could guess what kind of problems might be faced.

The workshop design guide required students to define their audiences and conduct a technology integration needs assessment with at least two people in their disciplinary area. Next, they were asked to design activities to engage their audience with TPACK. The analysis revealed that students integrated the data (e.g., context, infrastructure, technology skills) they gathered from the needs assessments into the design of TPACK activities. For example, the mathematics education team conducted interviews with in-service mathematics teachers to collect information about the integration of technology into their courses. They later formed their objectives (i.e., gain information concerning how to effectively integrate technologies specific to mathematics teaching during lesson planning) and designed workshop activities to meet each objective (i.e., demonstration of content-specific TPACK examples and lesson plans).

\section{Technological proficiency}

Half of the students acknowledged the importance of exploration in developing their knowledge of technology integration. The fifth TPACK-DBL principle (investigation of ICT tools) was integrated into the design guides, where students were required to examine and report the features, affordances, and limitations of a number of technologies. For example, in their TechDemos, they were asked to analyse the technology's main features, affordances, and limitations, as well as potential integration into and examples within teacher education contexts. Khan, when asked to evaluate the development of their understanding of TPACK-inaction throughout the course, commented in his reflection, "Seeing types of technologies contributed to me very much. We encountered new technologies that I didn't know before, and I learned how to use these technologies in the TECH demos." While designing the workshops, students were asked to analyse the technologies that they planned to integrate by providing information on setup, plus locating and linking to resources and preparation procedures. The technology analysis process was critical in increasing students' competencies with tools that they used in their workshops.

\section{Sustainable learning of TPACK}

To understand the impact of the design activities on the students, they were asked to reflect on how they would ensure the sustainability of their learning and the continuity of learning for teachers, pre-service teachers, and teacher educators. Four students stated that they began to consider TPACK as a research topic for future studies. Another two students considered conducting activities within their workplaces to put 
TPACK into practice, apply new strategies they had learned, and develop others' TPACK. Kay provided an example:

I can ensure the continuity of my learning and also others by creating a community of practice on TPACK. This community will consist of pre-service teachers, teacher educators, and teachers. All the participants can interact with each other. Teachers could learn about TPACK from me and other teacher educators. Teacher educators can develop their knowledge by conducting research on TPACK. Pre-service teachers can take courses about TPACK and interact with in-service teachers that use TPACK in field experiences.

Another student, Jim, shared his future plans:

As I am about to change my workplace, I believe I can elaborate more upon my knowledge of TPACK by putting it into practice, by means of personal reflection. If given the chance, I'd like to conduct studies with other instructors to contribute to my community. Now that I can add TPACK to my interests, I am ready for collaboration with professionals from all over the world.

Another activity, the Wikibook, was considered an artefact that could contribute to the world literature on TPACK. One student explained how the Wikibook might have a global impact because people around the world could read their chapters.

\section{To what extent did students enact TPACK-DBL principles in their workshops?}

The analysis revealed four principles that were explicitly included in the implementation process: engagement with theoretical knowledge, examination of design examples, design of technology-integrated artefacts, and reflection on design experiences.

Engagement with theoretical knowledge

All four groups planned activities to engage their participants with TPACK, primarily by conducting short presentations. These presentations first focused on the role of technology in their disciplines (e.g., mathematics education). However, the content of these presentations changed according to the needs and skill levels of their participants. For example, the mathematics and science education groups, who conducted their workshops with 10 in-service mathematics teachers and 30 third-year pre-service science teachers, respectively, first introduced PCK as a frame for teacher knowledge and then continued adding technology components into the lessons. The mathematics education group's design guide included the following description where they were asked how their presentation activity addressed TPACK:

In-service teachers may have not heard of the framework of TPACK, or even PCK, in their preservice teaching education. Therefore, they are far from knowing the implementation of TPACK in mathematics education. Lacking such important information seems to create a gap in their courses. We plan to close this gap as much as possible by using such presentation.

Examining design examples

The second TPACK-DBL principle that was implemented in all the workshops was the demonstration of content-specific TPACK examples and lesson plans. Students shared several plans that they prepared during the TPACK game as exemplary lessons in their disciplines:

- using blogging and Paint for a problem-based learning activity related to mirrors in science education

- $\quad$ using a podcast with problem-based learning about cyber-crimes in an information technology systems unit of an eighth-grade ICT course

- $\quad$ using a smart board for teaching functions and types of graphs

- using blogging to teach grammar in EFL classrooms. 
During these demonstrations, all workshop groups used a guided discussion where they asked participants to identify technology, pedagogy, and content in the lesson plans and focus on the intersections of these in the activities.

Designing technology-integrated artefacts

All workshop groups played variations of the TPACK game with their participants. Thus, they prepared pools of technology, content, and pedagogy items in their discipline areas as well as guiding questions and directions. They asked their participants to design a lesson plan with components selected from the pools. The mathematics education group had their participant groups present their lesson plans and explain why they selected certain technologies to teach mathematics content. The science education group described their TPACK game for pre-service science teachers in their design guide:

Four technologies (Diigo, Infographics, Simulations, and Blogging) will be introduced to the PSTs at the beginning of the workshop. Then, eight groups will be formed and assigned to a technology. Two of the groups will be using the same technology to prepare a lesson plan with the pedagogy and content they selected. Students will try to demonstrate their TPACK by preparing lesson plans. Moreover, since two groups will be using the same technology but different pedagogies and contents, they will be able to compare the usage of a technology with different teaching methods and contents.

\section{Reflecting on design experiences}

In their design guides, students were asked to facilitate a dialogue on TPACK and provide potential questions for discussion. The analysis of these questions revealed that students' guided dialogue on TPACK focused on participants' thoughts about the role and necessity of technology in their respective disciplinary areas, the value of TPACK in learning about technology integration, and strengths and weaknesses of the workshop activities. In addition to the reflection session, students collected data from their participants through interviews, technology integration assessment rubrics, and questionnaires to assess their knowledge and attitudes about TPACK.

\section{Discussion}

This study examined the way a TPACK-DBL approach facilitated students' understanding of TPACK-inaction in the context of a custom-designed graduate course. The analysis revealed that as students engaged in design activities to explore TPACK, they developed an understanding of TPACK-in-action across four dimensions: TPACK theory and practice connection, readiness for practice, technology proficiency, and sustainable learning of TPACK. All students were able to apply their learning to practice, as they delivered TPACK workshops in different contexts with different participants. Specifically, the analysis of their reflections indicated that they considered design activities as critical contributors to their development of TPACK-in-action. The findings are in line with the current research on DBL, which has also reported increased TPACK competencies of participants (Agyei \& Voogt, 2012; Chien et al., 2012; Fransson \& Holmberg, 2012; Graham et al., 2012; Hofer \& Grandgenett, 2012; Kafyulilo, 2010; Koehler et al., 2007; Koehler \& Mishra, 2005b; Kurt, 2012; Rienties et al., 2013; Shin et al., 2009; Timur, 2011). This study further contributes to the current literature by identifying how TPACK-DBL principles could be implemented within a course context and how these principles could contribute to students' understanding of TPACK-inaction.

Previous research has suggested that preparing teachers for a multifaceted environment requires varied opportunities for planning, applying, and reflecting on situated learning experiences related to technology integration in authentic contexts (Tondeur et al., 2012). Koh and Tsai (2014) urged researchers to conduct indepth qualitative studies within ICT courses to understand how teachers design lessons. Recent research follows a more integrated approach, designing courses that connect TPACK theory with practice. For example, Mouza et al. (2014) identified instructional design, authentic experiences, reflection, and applying 
theory to practice as critical components of effective teacher preparation in ICT courses that follow an integrative approach. Similarly, the current course's activities offered students opportunities to learn and teach TPACK, contributing to their understanding of TPACK-in-action. Specifically, the greatest development in their understanding occurred where technological, pedagogical, and content knowledge meet and constitute TPACK. Angeli and Valanides (2009) argued that while knowledge of content, pedagogy, and technology contribute to TPACK, they do not lead to automatic growth. The transformative view was followed in the design of the course activities that intentionally and exclusively targeted TPACK with the TPACK-DBL principles.

TPACK-DBL emphasises that TPACK as a unique body of knowledge is deeply situated in design and teaching practices. The TPACK framework emerged from a need to provide teachers contextual, situated, and authentic learning experiences that reflect real life environments where teachers constantly engage in problem-solving and decision-making regarding effective technology integration (Koehler \& Mishra, 2005a). Expanding on previous work, TPACK-DBL focuses on applying authentic design settings to help students understand practical representations of TPACK. Recent research on TPACK has highlighted the importance of pre-service teachers' enacting technology-enriched lessons in addition to designing them (Voogt et al., 2013). Therefore, the situated perspective of TPACK-DBL emphasised the development of students' contextual and practical TPACK (Angeli \& Valanides, 2009). For example, while designing technologyintegrated artefacts, students were given active roles in defining and resolving problems. As they prepared a technology-integrated lesson plan, students needed to consider contextual factors such as sequence of content, learners' skills and misconceptions, available technologies, affordances of possible technologies, instructional approaches, and classroom management procedures. The observed development in the areas of theorypractice connection, readiness for application, technology proficiency, and sustainable learning of TPACK showed that carefully structured design tasks that address teachers' situated learning in authentic contexts may facilitate understanding of TPACK-in-action.

Research findings on TPACK and DBL indicate that design projects seem to improve TPACK development. However, the ways these activities are organised and facilitated are important. Koh and Divaharan (2013), for example, suggested using pre-design activities to increase confidence and familiarity with technologies. TPACK-DBL considers technology exploration part of the design process, where learners explore the affordances and limitations of technologies while designing technology-integrated artefacts. The approach tends not to present these principles as step-by-step procedures but as varied elements of design that may be integrated into teacher education settings as a whole or in different combinations. The integration of TPACKDBL principles into a teacher education context, therefore, needs to be guided by teacher educators' instructional design decisions, contextual conditions, and the needs of the TPACK learners.

\section{Conclusions and future directions}

This study addresses key gaps in the corpus of research on the implementation of DBL as an approach for developing TPACK. First, whereas previous research has focused on TPACK development with DBL (Koehler et al., 2007; Pamuk, 2012), this study further identified DBL principles that facilitate students' understanding of TPACK-in-action through authentic design activities. Second, this research attempted to conceptualise DBL as a critical pedagogical approach to be integrated into teacher education programs. Finally, this study offered findings on the integration of TPACK-DBL into teacher education contexts that could help to shape subsequent pre-service and in-service teacher education programs in deliberate ways and to produce recommendations on the development of robust and high impact teacher education experiences.

While this TPACK-DBL course seemed to contribute to students' understanding of TPACK-in-action, the time and contexts were still limited in observing the continuity of learning and practice. Studies have revealed that long-term commitment is needed for TPACK because effective technology integration knowledge develops over time as teachers practise and develop expertise in connecting pedagogy, content, and technology (Agyei \& Voogt, 2012; Guzey \& Roehrig, 2009). Long-term exposure to effective technology integration activities in pre-service teacher education programs and in-service teachers' professional 
development programs may have the potential to deepen TPACK (Koh \& Divaharan, 2011). Further research is needed to design long-term programs with TPACK-DBL and examine its effect on pre-service and inservice teachers' continuity and sustained commitment to learn and apply TPACK in their unique contexts. Because design activities need to be integrated with other instructional strategies (Koh \& Divaharan, 2011), further research could also look at how the TPACK-DBL principles may be used with problem-based or project-based learning in teacher education programs.

The findings of the current study reveal that TPACK-DBL facilitated TPACK development. However, the results can be explained only within the contextual boundaries of this case study. Hence, the TPACK-DBL approach should be further investigated to understand how the findings of this case could transfer to other contexts and how adaptations of this approach could contribute to the development of pre-service teachers', in-service teachers', and teacher educators' TPACK. Future research that adopts and improves the proposed approach to facilitate the development of TPACK in different teacher education contexts will be critical.

\section{References}

Agyei, D. D., \& Voogt, J. (2012). Developing technological pedagogical content knowledge in pre-service mathematics teachers through collaborative design. Australasian Journal of Educational Technology, 28(4), 547-564. Retrieved from http://ajet.org.au/index.php/AJET/article/view/827/124

Alayyar, G. (2011). Developing pre-service teacher competencies for ICT integration through design teams (Doctoral dissertation). University of Twente, Enschede, the Netherlands. doi:10.3990/1.9789036532341

Angeli, C., \& Valanides, N. (2009). Epistemological and methodological issues for the conceptualization, development, and assessment of ICT-TPCK: Advances in technological pedagogical content knowledge (TPCK). Computers \& Education, 52(2009), 154-168. doi:10.1016/j.compedu.2008.07.006

Braun, V., \& Clarke, V. (2006). Using thematic analysis in psychology. Qualitative Research in Psychology, 3, 77-101. doi:10.1191/1478088706qp063oa

Chai, C. S., Koh, J. H. L., \& Tsai, C.-C. (2010). Facilitating preservice teachers' development of technological, pedagogical, and content knowledge (TPACK). Educational Technology \& Society, 13(4), 63-73. Retrieved from http://www.ifets.info/journals/13 4/7.pdf

Chai, C. S., Koh, J. H. L., \& Tsai, C.-C. (2013). A review of technological pedagogical content knowledge. Educational Technology \& Society, 16(2), 31-51. Retrieved from http://www.ifets.info/journals/16_2/4.pdf

Chien, Y.-T., Chang, C.-Y., Yeh, T.-K., \& Chang, K.-E. (2012). Engaging pre-service science teachers to act as active designers of technology integration: A MAGDAIRE framework. Teaching and Teacher Education: An International Journal of Research and Studies, 28(4), 578-588. doi:10.1016/j.tate.2011.12.005

Fransson, G., \& Holmberg, J. (2012). Understanding the theoretical framework of technological pedagogical content knowledge: A collaborative self-study to understand teaching practice and aspects of knowledge. Studying Teacher Education, 8(2), 193-204. doi:10.1080/17425964.2012.692994

Graham, C. R., Borup, J. J., \& Smith, N. B. (2012). Using TPACK as a framework to understand teacher candidates' technology integration decisions. Journal of Computer Assisted Learning, 28(6), 530-546. doi:10.1111/j.1365-2729.2011.00472.x

Guzey, S. S., \& Roehrig, G. H. (2009). Teaching science with technology: Case studies of science teachers' development of technology, pedagogy, and content knowledge. Contemporary Issues in Technology and Teacher Education, 9(1), 25-45. Retrieved from http://www.citejournal.org/articles/v9i1science1.pdf

Harris, J., Grandgenett, N., \& Hofer, M. (2010). Testing a TPACK-based technology integration assessment rubric. In C. D. Maddux, D. Gibson, \& B. Dodge (Eds.), Research highlights in technology and teacher education 2010, pp. 323-331. Chesapeake, VA: Society for Information Technology \& Teacher Education (SITE).

Harris, J., \& Hofer, M. (2011). Technological pedagogical content knowledge (TPACK) in action: A descriptive study of secondary teachers' curriculum-based, technology-related instructional planning. Journal of Research on Technology in Education, 43(3), 211-229. doi:10.1080/15391523.2011.10782570 
Hofer, M., \& Grandgenett, N. (2012). TPACK development in teacher education: A longitudinal study of preservice teachers in a secondary M.A.Ed. program. Journal of Research on Technology in Education, 45(1), 83-106. doi:10.1080/15391523.2012.10782598

Jang, S.-J., \& Chen, K.-C. (2010). From PCK to TPACK: Developing a transformative model for pre-service science teachers. Journal of Science Education and Technology, 19(6), 553-564. doi:10.1007/s10956-0109222-y

Jimoyiannis, A. (2010). Designing and implementing an integrated technological pedagogical science knowledge framework for science teachers' professional development. Computers \& Education, 55(2010), 1259-1269. doi:10.1016/j.compedu.2010.05.022

Jimoyiannis, A., Tsiotakis, P., Roussinos, D., \& Siorenta, A. (2013). Preparing teachers to integrate web 2.0 in school practice: Toward a framework for pedagogy 2.0. Australasian Journal of Educational Technology, 29(2), 248-267. Retrieved from http://ajet.org.au/index.php/AJET/article/view/157/55

Johnson, L. D. (2012). The effect of design teams on pre-service teachers' technology integration (Unpublished doctoral dissertation). Syracuse University, Syracuse, NY.

Kafyulilo, A. C. (2010). Practical use of ICT in science and mathematics teachers' training at Dar es Salaam University College of Education: An analysis of prospective teachers' technological pedagogical content knowledge (Unpublished master's thesis). University of Twente, Enschede, Netherlands.

Koehler, M., \& Mishra, P. (2005a). Teachers learning technology by design. Journal of Computing in Teacher Education, 21(3), 94-102. doi:10.1080/10402454.2005.10784518

Koehler, M., \& Mishra, P. (2005b). What happens when teachers design educational technology? The development of technological pedagogical content knowledge. Journal of Educational Computing Research, 32(2), 131-152. doi:10.2190/0ew7-01wb-bkhl-qdyv

Koehler, M., Mishra, P., Hershey, K., \& Peruski, L. (2004). With a little help from your students: A new model for faculty development and online course design. Journal of Technology and Teacher Education, 12(1), 25-55. Retrieved from http://www.editlib.org/p/14636/

Koehler, M., Mishra, P., \& Yahya, K. (2007). Tracing the development of teacher knowledge in a design seminar: Integrating content, pedagogy, \& technology. Computers \& Education, 49(3), 740-762. doi:10.1016/j.compedu.2005.11.012

Koh, J. H. L., \& Chai, C. S. (2014). Teacher clusters and their perceptions of technological pedagogical content knowledge (TPACK) development through ICT lesson design. Computers \& Education, 70, 222 232. doi:10.1016/j.compedu.2013.08.017

Koh, J. H. L., \& Divaharan S. (2011). Developing pre-service teachers' technology integration expertise through the TPACK developing instructional model. Journal Educational Computing Research, 44(1), 35-58. doi:10.2190/EC.44.1.c

Koh, J. H. L., \& Divaharan, S. (2013). Towards a TPACK-fostering ICT instructional process for teachers: Lessons from the implementation of interactive whiteboard instruction. Australasian Journal of Educational Technology, 29(2), 233-247. Retrieved from http://ajet.org.au/index.php/AJET/article/view/97/54

Kurt, G. (2012). Developing technological pedagogical content knowledge of Turkish pre-service teachers of English through a design study (Unpublished doctoral dissertation). Yeditepe University, Istanbul, Turkey.

Lincoln, Y., \& Guba, E. (2002). The only generalization is: There is no generalization. In R. Gomm, M. Hammersley, \& P. Foster (Eds.), Case study method (pp. 27-44). London, UK: Sage. doi:10.4135/9780857024367.d6

Mishra, P., \& Koehler, M. (2006). Technological pedagogical content knowledge: A framework for teacher knowledge. Teachers College Record, 108(6), 1017-1054. doi:10.1111/j.1467-9620.2006.00684.x

Mouza, C., Karchmer-Klein, R., Nandakumar, R., Yilmaz Ozden, S., \& Hu, L. (2014). Investigating the impact of an integrated approach to the development of preservice teachers' technological pedagogical content knowledge (TPACK). Computers \& Education, 71(2014), 206-221. doi:10.1016/j.compedu.2013.09.020

Pamuk, S. (2012). Understanding pre-service teachers' technology use through TPACK framework. Journal of computer assisted learning, 28(5), 425-439. doi:10.1111/j.1365-2729.2011.00447.x 
Prieto, L. P., Villagrá-Sobrino, S., Jorrín-Abellán, I. M., Martínez-Monés, A., \& Dimitriadis, Y. (2011). Recurrent routines: Analyzing and supporting orchestration in technology-enhanced primary classrooms. Computers \& Education, 57(1), 1214-1227. doi:10.1016/j.compedu.2011.01.001

Richardson, K. W. (2010). TPACK: Game on. Learning \& Leading with Technology, 37(8), 34-35. Retrieved from http://leadinginnovation1 1t.wikispaces.com/file/view/TPACK+game+on.pdf

Rienties, B., Brouwer, N., \& Lygo-Baker, S. (2013). The effects of online professional development on higher education teachers' beliefs and intentions towards learning facilitation and technology. Teaching and Teacher Education, 29, 122-131. doi:10.1016/j.tate.2012.09.002

Shin, T., Koehler, M., Mishra, P., Schmidt, D., Baran, E., \& Thompson, A. (2009). Changing technological pedagogical content knowledge (TPACK) through course experiences. In I. Gibson et al. (Eds.), Proceedings of Society for Information Technology \& Teacher Education International Conference 2009 (pp. 4152-4159). Chesapeake, VA: AACE.

Simon, H. A. (1969). The sciences of the artificial. Cambridge, MA: The MIT Press.

Srisawasdi, N. (2012). The role of TPACK in physics classroom: Case studies of pre-service physics teachers. Procedia - Social and Behavioral Sciences, 46, 3235-3243. doi:10.1016/j.sbspro.2012.06.043

Timur, B. (2011). The development of pre-service science teachers' technological pedagogical content knowledge in force and movement subjects (Doctoral dissertation). Gazi University, Ankara, Turkey.

Tondeur, J., van Braak, J., Sang, G., Voogt, J., Fisser, P., \& Ottenbreit-Leftwhich, A. (2012). Preparing preservice teachers to integrate technology in education: A synthesis of qualitative evidence. Computers \& Education, 59(2012), 134-144. doi:10.1016/j.compedu.2011.10.009

Voogt, J., Fisser, P., Pareja Roblin, N., Tondeur, J., \& van Braak , J. (2013). Technological pedagogical content knowledge: A review of the literature. Journal of Computer Assisted Learning, 29, 109-121. doi:10.1111/j.1365-2729.2012.00487.x

Yin, R. (2003). Case study research: Design and methods (3rd ed.). Thousand Oaks, CA: Sage.

Corresponding author: Evrim Baran, ebaran@metu.edu.tr

Australasian Journal of Educational Technology (C) 2016.

Please cite as: Baran, E., \& Uygun, E. (2016). Putting technological, pedagogical, and content knowledge (TPACK) in action: An integrated TPACK-design-based learning (DBL) approach. Australasian Journal of Educational Technology, 32(2), 47-63. 